\title{
Eating behaviour of young rats: experiment on selective feeding on diet and sugar solution
}

\author{
By SHIZUKO MUTO AND CHIHOKO MIYAHARA \\ Laboratory of Infant Nutrition, fapan Women's University, Tokyo, fapan
}

(Received ${ }_{13}$ October 1971 - Accepted 2 June 1972)

\begin{abstract}
1. The study set out to examine the suggestion that a child's spontaneous selection of food is guided by a need for specific nutrients rather than by a simple expression of his taste.

2. Newly weaned rats were divided into two groups; one was fed on a high-protein diet (HP) and the other one on a low-protein diet (LP). Each group was divided to two sub groups; one given $40 \%$ sucrose solution (HPS and LPS) and the other not (HPO and LPO).

3. They were kept in individual cages and observed for 9 weeks. HPO and LPO wete permitted free access to the diet and water, and HPS and LPS to the dict, water and the sugar solution. The latter groups consumed sugar regardless of the protein content of their diet and the energy derived from sugar reached nearly $50 \%$ of total energy at the end of the experimental period.

4. Both HP groups gained weight at about the same rate, with LPO rats making poorer growth and LPS rats still poorer growth.

5. Liver fat content of LPS was significantly high compared with other groups and the correlation coefficient for sugar intake and liver fat content was high within the group.

6. The weight of femur, and its calcium and mineral content were parallel with the bodyweight, that of L.PS being the lowest.

7. It was concluded that the young rat would choose a considerable amount of sugar, cven sacrificing its growth and health when its daily diet was poor in protein.
\end{abstract}

There has been much controversy as to whether animals have an inborn drive to select foods which fulfil their physiological requirements (Davis, 1928, 1934; Harris, Clay, Hargreaves \& Ward, I933; Richter \& Barelare, 1938; Richter, Holt \& Barelare, 1938; Barnett \& Spencer, 1953), or whether they will eat what they enjoy regardless of its effects on health (Kon, I931; Scott, 1946).

Macy (1942) suggested that the child would not crave for sweets if his diet was well balanced, but after reviewing the literature, the American Academy of Pediatrics: Committee on Nutrition ( $\left.19^{64}\right)$ commented that the science of nutrition seemed a more reliable guide to food selection than the child's natural desire. The present experiment was designed to see whether young rats with access to a well-balanced diet would allow their natural liking for sugar to unbalance it.

\section{EXPERIMENTAL}

Twenty newly weaned male Wister rats, five lots each of four litter-mates, were divided into four groups of five with one of the four siblings in each group. The rats weighed about $5 \circ \mathrm{g}$. Two groups were fed on a balanced high-protein diet (HP) and the other two groups on a low-protein diet (LP). One HP and one LP group were permitted free access to $40 \%$ sucrose solution as well as to water, and designated HPS and LPS; the other two groups were fed without sugar solution, and designated HPO and LPO. 
Table I. Composition of diets given to the experimental groups of rats

\begin{tabular}{|c|c|c|c|c|}
\hline & \multicolumn{2}{|c|}{ Group given high-protein diet } & \multicolumn{2}{|c|}{ Group given low-protein diet } \\
\hline & $\begin{array}{l}\text { With sugar } \\
\text { (HPS) }\end{array}$ & $\begin{array}{l}\text { Without sugar } \\
\text { (HPO) }\end{array}$ & $\begin{array}{l}\text { With sugat } \\
\text { (LPS) }\end{array}$ & $\begin{array}{l}\text { Without sugar } \\
\text { (LPO) }\end{array}$ \\
\hline $40 \%$ sugar solution & Ad lib. & $\circ$ & Ad lib. & 0 \\
\hline Composition of diet $(\%)$ & & & & \\
\hline Casein & I 8 & I 8 & 9 & 9 \\
\hline Maize starch & 72 & 72 & $8 \mathrm{I}$ & 81 \\
\hline Soya-bean oil & 5 & 5 & 5 & 5 \\
\hline Vitamin mixture* & $\mathrm{I}$ & I & I & I \\
\hline Salt mixturet & 4 & 4 & 4 & 4 \\
\hline Choline chloride & 0.15 & 0.15 & 0.15 & 0.15 \\
\hline
\end{tabular}

* Contained (per g) : vitamin A palmitate 2500 i.u., thiamin mononitrate I mg, nicotinic acid $10 \mathrm{mg}$, folic acid $0.5 \mathrm{mg}$, cyanocobalamin I $\mu \mathrm{g}$, DL- $\alpha$-tocopheryl acetate I $\mathrm{mg}$, ergocalciferol 200 i.u., riboflavin $1.5 \mathrm{mg}$, pyridoxine hydrochloride $\mathrm{I} \mathrm{mg}$, calcium pantothenate $5 \mathrm{mg}$, ascorbic acid $37.5 \mathrm{mg}$.

$\dagger$ Contained (g/roo g): $\mathrm{CaCO}_{3}$ 29.29, $\mathrm{CaHPO}_{4} .2 \mathrm{H}_{2} \mathrm{O} 0.43, \mathrm{KH}_{2} \mathrm{PO}_{4} 34.3 \mathrm{I}, \mathrm{NaCl} 25^{\circ} \cdot 06$, $\mathrm{MgSO}_{4} \cdot 7 \mathrm{H}_{2} \mathrm{O} 9.98, \mathrm{Fe}\left(\mathrm{C}_{6} \mathrm{H}_{5} \mathrm{O}_{7}\right) .6 \mathrm{H}_{2} \mathrm{O} 0.623, \mathrm{CuSO}_{4} .5 \mathrm{H}_{2} \mathrm{O}$ o.r $56, \mathrm{MnSO}_{4} \cdot \mathrm{H}_{2} \mathrm{O} 0.12 \mathrm{I}, \mathrm{ZnCl}_{2} 0.02$, $\mathrm{KI} 0.0005,\left(\mathrm{NH}_{4}\right)_{6} \mathrm{Mo}_{7} \mathrm{O}_{24} \cdot 4 \mathrm{H}_{2} \mathrm{O} 0.0025$.

Table I gives the compositions of the high- and low-protein diets. The diet was given by cup; sugar solution and water by bottle. The food was renewed every other day.

The animals were housed in individual cages in an air-conditioned room and fed ad lib. for 9 weeks. During this time general health, faeces, hair and activity were closely observed. The body-weight, the tail length and the amounts of the diet and sugar solution consumed by the rats were measured every other day.

At the end of the 9-week experimental period the animals were killed with diethyl ether, and the liver, kidneys, spleen, adrenal glands, heart and lungs were weighed. Fat deposits around the kidneys and the testes, and beneath the skin of the abdomen, were carefully dissected out and weighed. The fat and nitrogen contents of the liver were determined, the former by the Soxhlet method and the latter by the microKjeldahl method. Bone development was judged by the length of the femur, its defatted dry weight, and its ash and calcium contents. The permanganate method was used for the calcium determination.

RESULTS

\section{Diet and sugar consumption}

In both sugar groups, HPS and LPS, sucrose intake increased rapidly during the first 3 weeks, from about ro $g$ to about $40 \mathrm{~g} /$ week. The sugar consumption of the LPS group then tended to level off, but that of the HPS group continued to rise, although less rapidly, reaching $62.5 \mathrm{~g} /$ week at the end of the $9^{\text {th }}$ week (Fig. I $a$ ).

Both HPS and LPS groups consumed less of the diet than the respective controls. The dietary intake of the HPS group and its control, HPO, increased rapidly at first and then more slowly up to the 5 th week, when the HPO's intake reached $130 \mathrm{~g} /$ week and that of the HPS Ioo g; the intake then fell gradually toward the final value at the 9th week. Throughout the experimental period the intake of the HPS group was less 

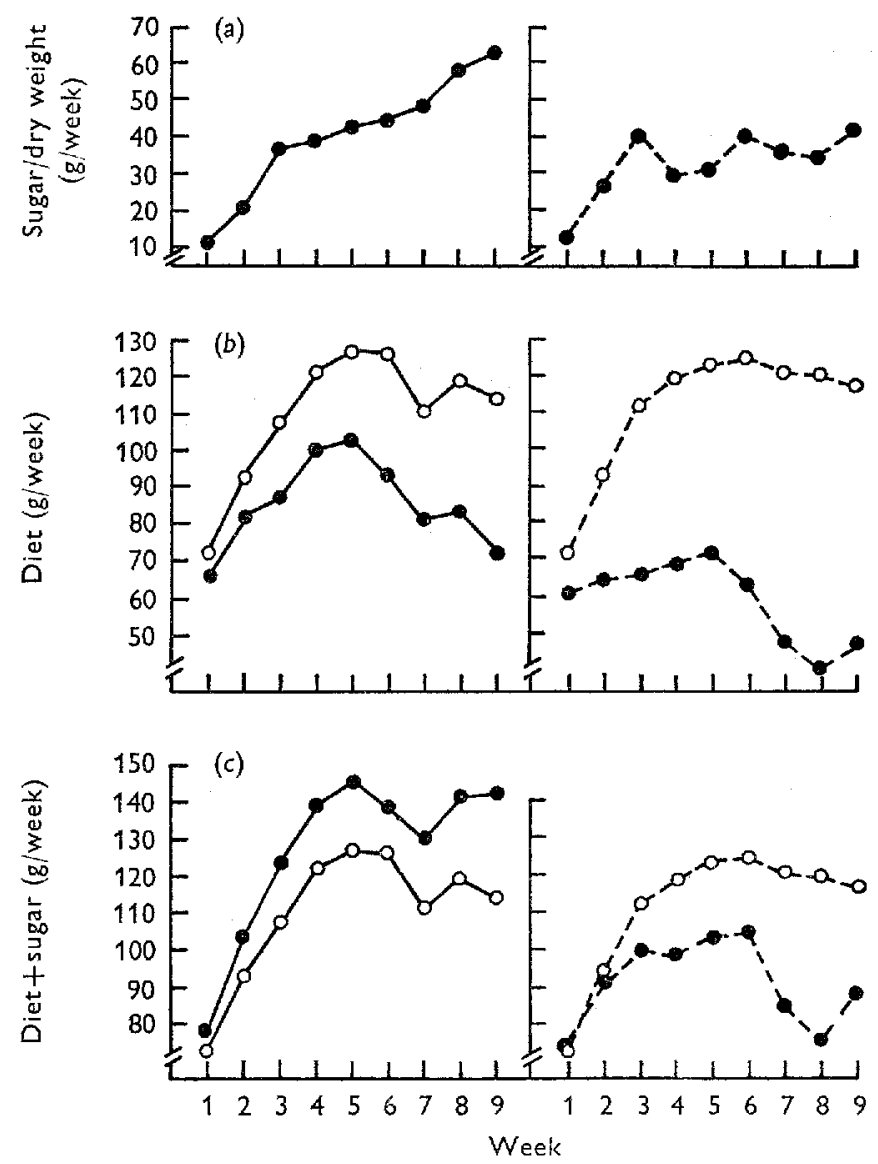

Fig. I. Mean values for sugar $(a)$, diet $(b)$ and diet + sugar $(c)$ intakes of five rats eating either a high- or a low-protein dict with or without additional sugar solution. - - , highprotein diet with sugar (HPS); $\mathrm{O}-\mathrm{O}$, high-protein diet without sugar (HPO); --low-protein diet with sugar (LPS); $\mathrm{O}---\mathrm{O}$, low-protein diet without sugar (LPO).

than that of the control group by $20 \mathrm{~g}$ (3rd week) to $40 \mathrm{~g}$ (9th week) (Fig. $\mathbf{I} b$ ). 'The sum of sugar + diet taken by the HPS group was a little higher than the total intake of its control and the peak of $150 \mathrm{~g} /$ week occurred at the $5^{\text {th }}$ week (Fig. I c ).

In the LP diet groups there was an appreciable difference in dietary intake pattern between the sugar group and non-sugar group. The intake of the LPO group reached a plateau of $125 \mathrm{~g} /$ week at the 6th week; unlike the HPO's dietary intake pattern, there was no marked decrease after that. The dietary intake of the LPS group was remarkably low in comparison with that of the LPO, there being only a slight increase before the $5^{\text {th }}$ week and a rapid decrease after that (Fig. I $b$ ). Accordingly, the sum of the sugar and diet intakes of the LPS group was considerably below that of its control, especially in the latter half of the experimental period, mainly owing to the rapid reduction of diet intake (Fig. I $c$ ). 

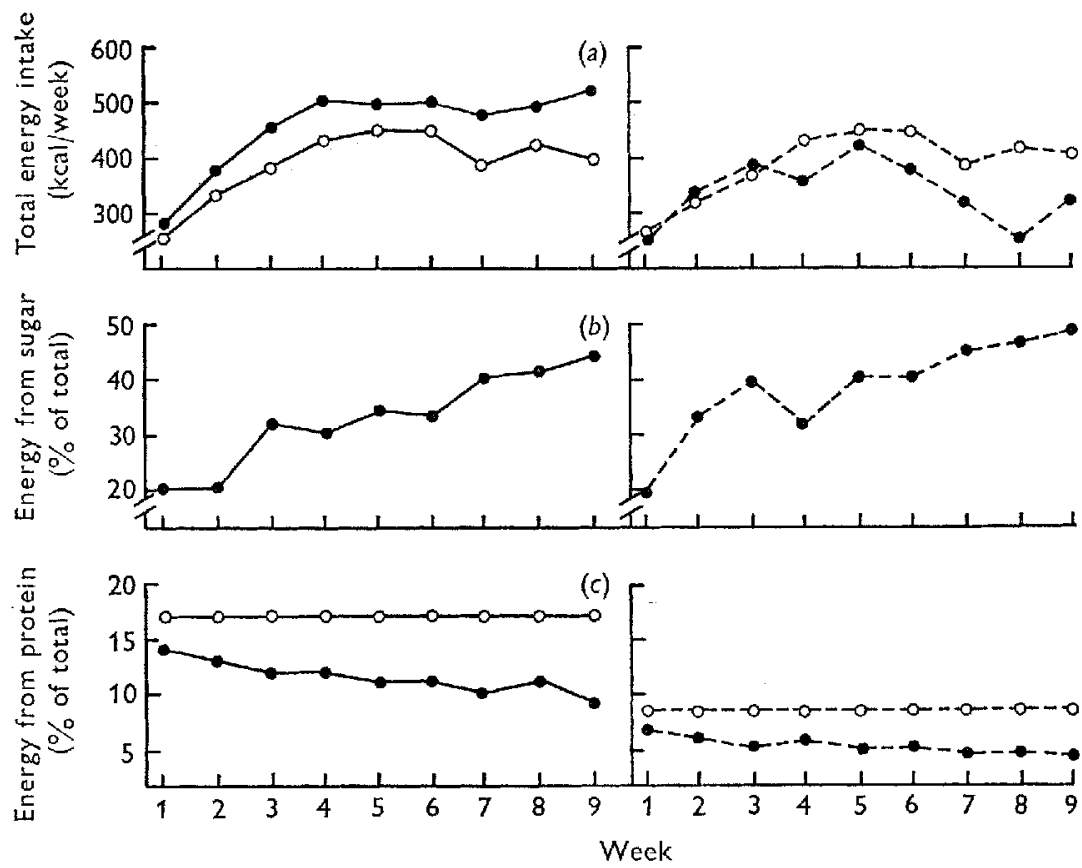

Fig. 2. Mean values for total energy intake, and for percentages of energy derived from sugar and from protein for five rats eating either a high- or a low-protein diet with or without additional sugar solution. - , high-protein diet with sugar (HPS); $\bigcirc-O$, high-protein diet without sugar (HPO); - - low-protein diet with sugar (LPS); $\mathrm{O}_{-}-\mathrm{O}$, lowprotein diet without sugar (LPO).

\section{Energy and protein intakes}

Total energy intakes of the HP and LP groups are shown in Fig. 2(a). The control groups, HPO and LPO, yielded nearly identical curves for energy intake, starting with $\mathrm{I} \cdot 05 \mathrm{MJ}(250 \mathrm{kcal}) /$ week, reaching the highest intake of about ${ }_{\mathrm{r}} \cdot 88 \mathrm{MJ}\left(45^{\circ} \mathrm{kcal}\right) /$ week by the $5^{\text {th }}$ week in HPO and the 6 th week in LPO.

The HPS group consistently took rather more energy than its control, whereas LPS consumed exactly the same amount of energy as LPO until the 3 rd week and less after that. At first, the proportion of energy derived from sugar was $20 \%$ in both HPS and LPS groups. In HPS the proportion gradually rose to $45 \%$ by the 9 th week (Fig. $2 b$ ) but in the LPS group it reached $40 \%$ within 3 weeks and then increased slowly up to $48 \%$ by the 9 th week.

The protein intakes of HPS and LPS were of course less than those of their nonsugar-eating controls, because the sugar intake replaced a proportion of the diet. In HPS, energy derived from protein started at $\mathrm{x} \%$ of total energy and gradually fell to $9 \%$ at the end of the experimental period. For LPS, the proportion decreased from $8 \%$ in the beginning to $4 \%$ at the end (Fig. 2 c). The HPO and LPO groups received a constant 18 and $9 \%$ respectively of the total energy from protein. 


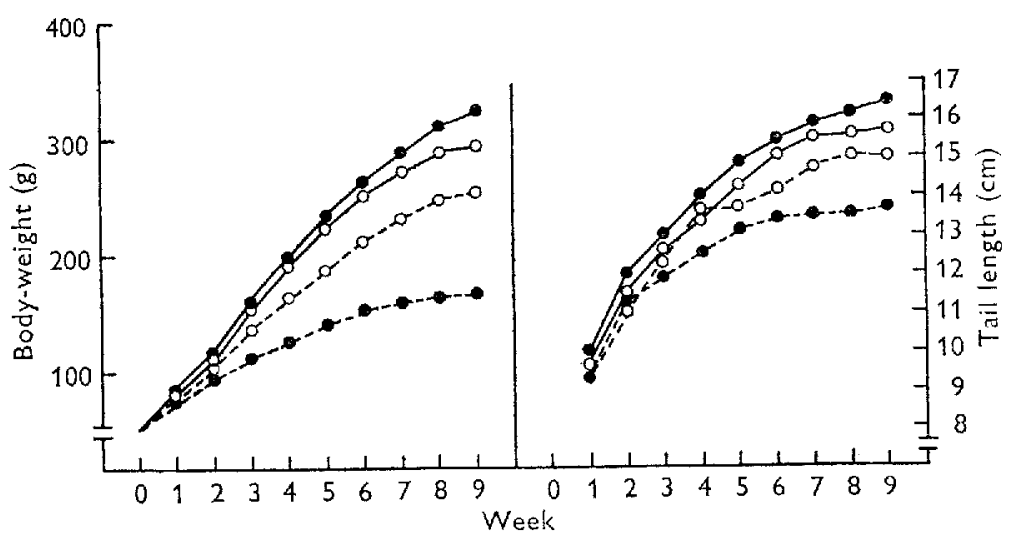

Fig. 3. Mean values for body-weight and tail length for five rats eating either a high- or a low-protein diet with or without additional sugar solution. $\longrightarrow$, high-protein diet with sugar (HPS); $\mathrm{O}-\mathrm{O}$, high-protein diet without sugar (HPO); -0 , low-protein diet with sugar (LPS); $\mathrm{O}---\mathrm{O}$, low-protein diet without sugar (LPO).

\section{Health}

Independent of consumption of sugar, both HPS and HPO were in good health throughout the experimental period as judged by faeces, hair and general activity. No diarrhoea was observed in the LP groups either, but in both these groups the hair became somewhat rough, and two LPO rats developed a haemorrhagic skin disease.

Subjectively, the LPO rats became less active and slower in their movements as time went on, while the LPS rats became rather nervous and restless.

\section{Body-weight and tail length}

The average body-weight and tail length of each group are shown in Fig. 3. The HP groups with or without sugar gained more weight than the LP groups.

Whereas the effect of sugar intake on the HP group was a slightly greater gain of body-weight, no doubt at least partly due to the somewhat greater energy intake, the effect of sugar on the LP group was to cause a clear depression of growth, which suggests that a more serious effect of sugar intake is exerted on a poorly fed rat than on one which is well fed. The growth of tail length roughly paralleled that of body-weight.

\section{Individual characteristics}

Marked differences in both sugar and dietary intakes, and weight gain were observed among individuals of each group. The sugar and dietary intakes and weight gain of the same rat also varied from day to day. There were relatively large, small, or fastidious sugar consumers, and large sugar consumption was not necessarily related to a small dietary intake; likewise a small sugar intake did not mean a large intake of the diet.

There was no obvious tendency for siblings to share the same tastes for sugar, although the number of animals used was too small for this to be tested. 


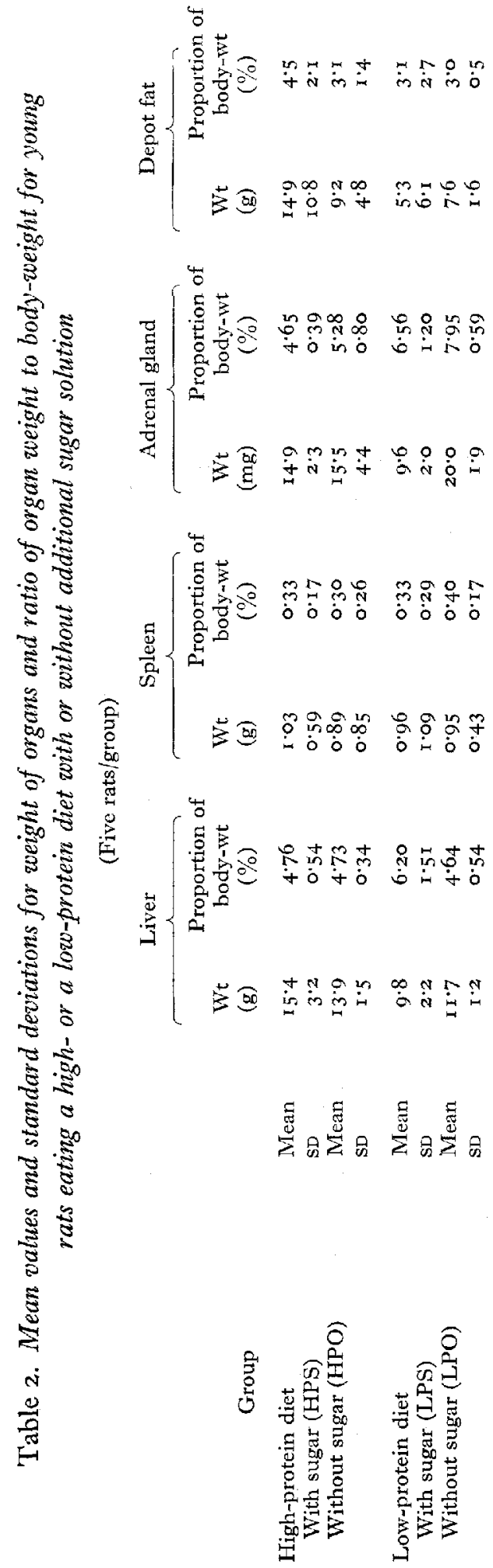


Vol. 28

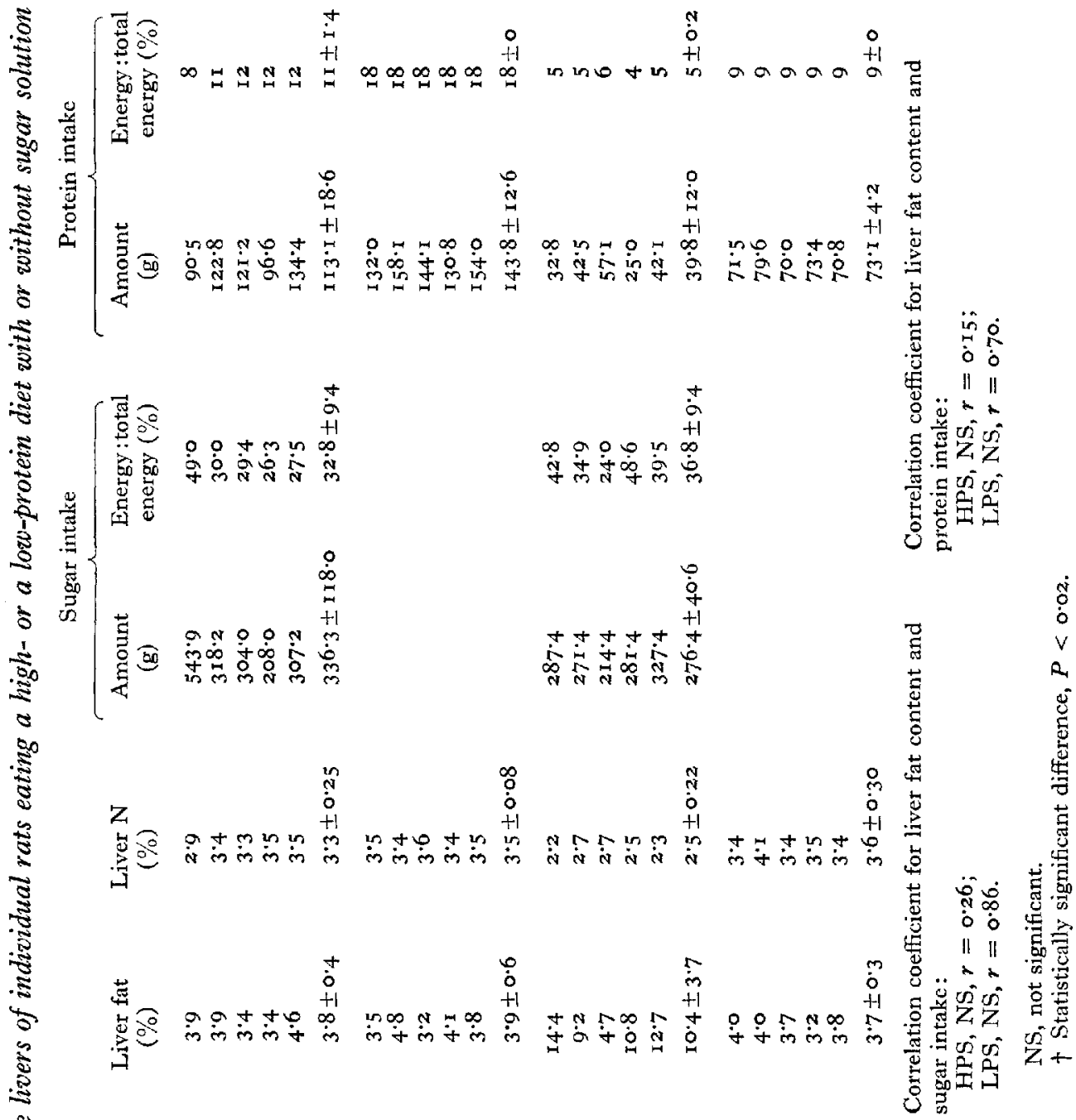

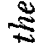

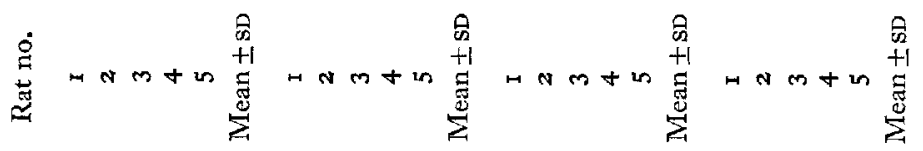

뭉

के

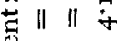

$\omega \sim \|$

䄱至"

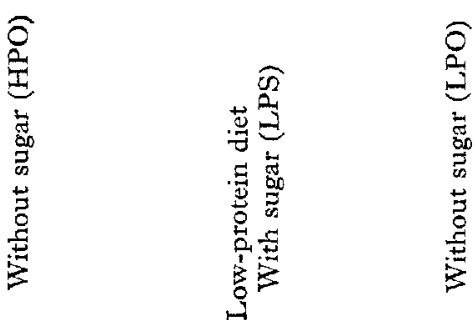

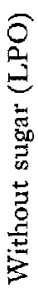
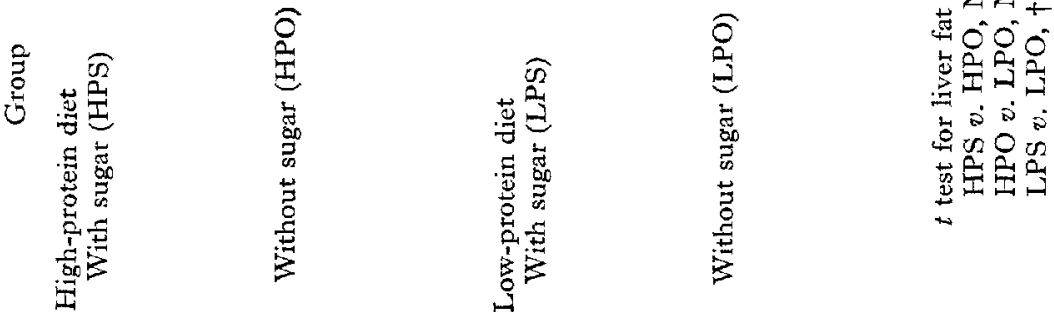
Table 4. Results, collected at the end of the 9-week experimental period, for the femur of rats eating a high-or a low-protein diet with or without sugar solution

(Mean values and standard deviations for five rats/group)

\begin{tabular}{|c|c|c|c|c|}
\hline & $\begin{array}{l}\text { High-protein } \\
\text { with sugar } \\
\text { (HPS) }\end{array}$ & $\begin{array}{l}\text { High-protein } \\
\text { without sugar } \\
\text { (HPO) }\end{array}$ & $\begin{array}{l}\text { Low-protein } \\
\text { with sugar } \\
\text { (LPS) }\end{array}$ & $\begin{array}{l}\text { Low-protein } \\
\text { without sugar } \\
\text { (LPO) }\end{array}$ \\
\hline Length $(\mathrm{cm})$ & $3.4 \pm 0.15$ & $3 \cdot 5 \pm 0.016$ & $3.0 \pm 0.21$ & $3.3 \pm 0.13$ \\
\hline Weight (g)† & $0.46 \pm 0.073$ & $0.46 \pm 0.072$ & $0.26 \pm 0.075$ & $0.37 \pm 0.33$ \\
\hline $\begin{array}{l}\text { Ash content } \\
\text { Wt (g) } \\
\text { As } \% \text { femur wt }\end{array}$ & $\begin{array}{c}0.273 \pm 0.040 \\
59 \pm 1.8\end{array}$ & $\begin{array}{c}0.269 \pm 0.204 \\
58 \pm 1 \cdot 0\end{array}$ & $\begin{array}{c}\text { O. I } 59 \pm 0.049 \\
6 \mathrm{I} \pm \mathrm{I} \cdot 7\end{array}$ & $\begin{array}{c}0.216 \pm 0.019 \\
59 \pm 3.3\end{array}$ \\
\hline $\begin{array}{l}\text { Calcium content } t \\
\text { Wt (g) } \\
\text { As } \% \text { fernur wt } \\
\text { As } \% \text { femur ash wt }\end{array}$ & $\begin{array}{c}0.103 \pm 0.180 \\
22.2 \pm 0.58 \\
37.7 \pm 0.08\end{array}$ & $\begin{array}{l}0.102 \pm 0.016 \\
22 \cdot 2 \pm 0.21 \\
38 \cdot 2 \pm 0.48\end{array}$ & $\begin{array}{l}0.061 \pm 0.020 \\
23.7 \pm 1.09 \\
38.3 \pm 0.36\end{array}$ & $\begin{array}{c}0.082 \pm 0.003 \\
22 \cdot 3 \pm 1 \cdot 28 \\
38 \cdot 5 \pm 0.90\end{array}$ \\
\hline Calcium intake ( $\mathrm{g} / \mathrm{rat})$ & $3.54 \pm 0.58$ & $4^{\cdot} 55 \pm 0 \cdot 38$ & $2 \cdot 43 \pm 0 \cdot 74$ & $4.50 \pm 0.23$ \\
\hline
\end{tabular}

$t$ test for: Femur length, LPS $v$. LPO, $*, t=3.57 \mathrm{I}$; Correlation coefficient between the amount of Femur weight, LPS $v$. LPO, *, $t=2 \cdot 973$; calcium in a femur and sugar intake:

Femur calcium content, LPS $v$. LPO, NS, $t=0.9 \mathrm{r}$;

HPS, NS, $r=-0.35 \circ$ L.PS, NS, $r=-0.58 z$.

Femur ash weight, LPS $v$. LPO, NS, $t=2 \cdot 435$.

Correlation coefficient between the amount of calcium in a femur and protein intake: HPS, NS, $r=-0.472$;

NS, not significant. LPS, **, $r=0.997$.

Statistically significant differences are indicated by: ${ }^{*} P<0 \cdot 05,{ }^{*} P<0.0$. + Defatted and dried femur.

\section{Weights of the organs}

Among the organs measured at the time of autopsy, the weights of the liver, spleen, adrenal glands and deposited fat, and the ratio of each organ weight to body-weight are presented in Table 2. Individual organ weights tended to maintain their relation to the body-weight except for the mean liver weight of the LPS rats, which was relatively great, and the mean adrenal gland weight of the LPO rats, which was heavier both absolutely and in relation to body-weight.

The amount of depot fat was highly variable but was on average roughly proportional to body-weight, except for the HPS group, in which both total depot fat and its relation to body-weight was somewhat raised.

\section{Fat and nitrogen contents of the liver (Table 3)}

The liver fat content of HPS, HPO, and LPO rats were about the same, ranging from 3.2 to $4.8 \%$, but the content of LPS was significantly higher (at the $2 \%$ level), averaging $10.4 \pm 3.7 \%$ (SD). One of the rats in LPS (no. 3) showed an exceptionally low value $(4.7 \%)$ of liver fat content compared with other samples in the same group. The sugar consumption of this exceptional subject was the lowest and its dietary intake, and consequently its protein intake, was the highest in the group. Although the correlation coefficients for the liver fat content and sugar intake and for the liver fat content and protein intake in HPS were positive but very small, that for 
the former being $r=0.26$ and that for the latter $r=0.15$, those in LPS were positive and considerably higher $(r=0.86)$, though not significant, for the liver fat content and sugar intake and $r=-0.70$ for the liver fat content and protein intake.

\section{Femurs (Table 4)}

The average length of the femur decreased in the order HPO, HPS, LPO and LPS. The differences in the lengths between groups were small except that the mean length of the LPS group was significantly shorter than that of its control group, LPO. The mean defatted and dried weights of the femurs of HPS and HPO rats were the same; the mean weight for the LPO group was considerably less and that for the LPS group was significantly less still.

The only rat of the LPS group which had a normal value for liver fat had a femur weight of $0.35 \mathrm{~g}$, within the range of the LPO group; the femur weights of the rest of the rats in the group, which all had fatty livers, ranged between 0.15 and $0.28 \mathrm{~g}$.

The weight of ash obtained from the femur was proportional to the weight of the bone. The calcium content of the femur was also closely proportional to bone weight and to ash content. These facts suggest that there is remarkable consistency in the bone structure independent of bone size or nutrient intake.

\section{DISCUSSION}

\section{Effects of sucrose consumption upon appetite}

In previous experiments along these lines a wide choice of nutrients was given: thirty-three natural foodstuffs by Davis (I928), eleven purified nutrients by Richter \& Barelare (1938) and Richter et al. (1938). By contrast, we have simplified the experimental situation in offering only two choices, sugar solution and a total mixed diet.

Given the opportunity, rats chose to consume considerable quantities of sugar and it had the effect of reducing the intake of their other diet. In the high-protein groups the energy intakes, whether from diet alone or from a combination of the diet and sucrose, were closely similar. This confirms the observation of Brobeck (I946), Mayer-Gross \& Walker (1946), McCleary (1953), Young (1957), Mook (1963) and of ourselves (Muto \& Mizuno, 1970) that the energy intake of healthy rats is governed by their appetites and is not affected by the sources of the energy. Even when $30 \%$ of the energy intake was as sucrose there was sufficient protein available from the diet, equivalent to an average of $\mathrm{II} \cdot 5 \%$ of the energy, to ensure that the sugar-eating rats remained healthy and grew as well as the controls whose diet contained protein equivalent to I $8.5 \%$ of the energy content.

The situation was otherwise with rats on the low-protein diets. Those with access to sugar also chose to take almost half their energy from this source, but in this group eating sugar had the effect of depressing total intake of food, an observation also made by Wiener, Yoshida \& Harper (1963).

What is the reason for the depressed appetite? Protein deficiency may play a part as has been suggested by Rose (r938) and Scott (1946). In terms of energy, the LPO group consumed as much as the HPO, so that their appetite was adequate. But growth 
rate was reduced, presumably owing to the lower protein intake, and a further reduction of protein, caused by substituting sucrose could have a more serious constitutional effect, evidenced, among other things, by a poor appetite. This effect probably appears when protein intake falls to between 5.5 and $9 \%$ of energy intake.

Another possible reason for depression of appetite could be thiamin deficiency, the sugar both reducing the intake of thiamin by reducing the intake of the normal diet and itself increasing the need for thiamin. The nervous, restless behaviour of the LPS rats might suggest thiamin deficiency.

The change in total body-weight and the amount of the depot fat showed an expected relation to energy intake, the HPS group eating more, growing more rapidly and becoming fatter than the HPO group, whereas the LPS group ate less, grew less well and accumulated less fat than the LPO group. In general, organ weights were approximately proportional to body-weight, but there were exceptions: an appreciably heavier liver and spleen in the HPS than in the HPO group and spleens of the same weight in both LP groups, for which we have no explanation.

The fatty livers characteristic of the LPS group is a feature of low-protein feeding. Reussner, Andros \& Thiessen (1963) reported the development of a high liver fat content with protein at a level of $6 \%$ of energy, and Wikramanayake (1966) when protein was below $5 \%$. A high-sucrose, low-protein diet gave a similar picture (Allen \& Leahy, 1966; Al-Nagdy, Miller, Qureshi \& Yudkin, 1966). Although the correlation between liver fat and dietary protein was not particularly close in our experiments, the evidence points to a protein level of about $6 \%$ as being critical; below that level, fat deposition in the liver will occur. To what extent sucrose intake, independent of protein level, affects liver fat cannot be answered from these results.

Bone development was similarly affected. Sugar intake, as such, had no noticeable effect on bone growth or mineralization, but poor bone growth and development were a feature with the low-protein diets, and the results are in accord with the findings for malnourished children by Dickerson \& John (1969).

The findings of this paper can be summarized as follows. If a high-quality diet is available to growing young rats, then unlimited access to sugar may cause a greater total energy intake and increased storage of body fat, but does not seriously impair the quality of the diet nor interfere with growth and development. On the other hand, if the quality of the basal diet is marginal, then access to sugar may result in a total diet which is so deficient in protein that it impedes growth and development. Morcover, if the quality of the diet is sufficiently poor, intake may be further prejudiced by impaired appetite.

It is not possible at this stage to draw analogies for the more slowly growing human young, but it is probably true of children, as of rats, that they have no strong instincts for eating the best-quality diet available and will eat what they fancy. 


\section{REFERENCES}

Allen, R. J. L. \& Leahy, J. S. (1966). Br. F. Nutr. 20, 339.

Al-Nagdy, S., Miller, D. S., Qureshi, R. U. \& Yudkin, J. (1966). Nature, Lond. 209, 8I.

American Academy of Pediatrics: Committee on Nutrition (1964). Pediatrics, Springfield 33, I35.

Barnett, S. A. \& Spencer, M. M. (1953). F. Hyg., Camb. 5x, r6.

Brobeck, J. R. (1946). Physiol. Rev. 26, 541.

Davis, C. M. (1928). Am. F. Dis. Childh. 36, 651.

Davis, C. M. (1934). F. Pediatrics 5, 573.

Dickerson, J. W. T. \& John, P. M. V. (1969). Br. F. Nutr. 23, 9 I7.

Harris, L. J., Clay, J., Hargreaves, F. J. \& Ward, A. (1933). Proc. R. Soc. B xx3, I6r.

Kon, S. K. (r93 r). Biochem. Ұ. 25, 473.

McCleary, R. A. (1953). 7. comp. physiol. Psychol. 46, 4I I .

Macy, I. C. (1942). Nutrition and Chemical Growth in Childhood Vol. I Evaluation p. 84. Springfield: Charles C. Thomas.

Mayer-Gross, W. \& Walker, J. W. (1946). Br. F. exp. Path. 27, 297.

Mook, D. G. (1963). F. comp. physiol. Psychol. 56, 645.

Muto, S. \& Mizuno, K. (1970). F. Jap. Soc. Fd Nutr. 23, 180.

Reussner, G. Jr Andros, J. \& Thiessen, R. Jr (1963). F. Nutr. 80, 29 I.

Richter, C. P. \& Barelare, B. Jr (I938). Endocrinology 23, I5.

Richter, C. P., Holt, L. E. Jr \& Barelare, B. Jr (1938). Am. F. Physiol. 122, 734.

Rose, W. C. (1938). Physiol. Rev. 18, 109.

Scott, E. M. (1946). F. Nutr. 31, 397.

Wiener, R. P., Yoshida, M. \& Harper, A. E. (1963). F. Nutr. 80, 279.

Wikramanayake, T. W. (r 966). Br. F. Nutr. 20, 64I.

Young, P. T. (1957). Am. F. clin. Nutr. 5, 154. 